\title{
Cu Photoredox Catalysts Supported by a 4,6-Disubstituted 2,2'- Bipyridine Ligand: Application in Chlorotrifluoromethylation of Alkenes
}

\author{
Murat Alkan-Zambada and Xile $\mathrm{Hu}^{*}$ (1) \\ Laboratory of Inorganic Synthesis and Catalysis, Institute of Chemical Sciences and Engineering, École Polytechnique Fédérale de \\ Lausanne (EPFL), ISIC-LSCI, BCH 3305, Lausanne 1015, Switzerland
}

Supporting Information

\begin{abstract}
Interest in base metal catalysis motivates the development of $\mathrm{Cu}$-based photoredox catalysts for organic synthesis. However, only a few $\mathrm{Cu}$ catalysts have been applied in photoredox reactions, the majority of which contain one or two 1,10-phenanthroline ligands. Here we design a 4,6-disubstituted 2,2'-bipyridine ligand for $\mathrm{Cu}$. Two heteroleptic $\left[\mathrm{Cu}\left(\mathrm{N}^{\wedge} \mathrm{N}\right)\left(\mathrm{P}^{\wedge} \mathrm{P}\right)\right]\left[\mathrm{PF}_{6}\right]$ complexes, where $\mathrm{N}^{\wedge} \mathrm{N}$ stands for the 2,2'-bipyridine ligand and $\mathrm{P}^{\wedge} \mathrm{P}$ stands for a bisphosphine ligand, have been synthesized and characterized. They exhibit longer excited state lifetimes and higher $\mathrm{Cu}(\mathrm{I}) / \mathrm{Cu}(\mathrm{II})$ potentials compared to the most widely used $\mathrm{Cu}$ catalyst, $[\mathrm{Cu}-$ $\left.(\mathrm{dap})_{2}\right] \mathrm{Cl}$. The complex with Xantphos as the $\mathrm{P}^{\wedge} \mathrm{P}$ ligand is an

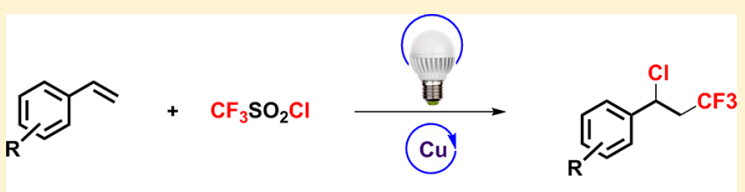
efficient catalyst for chlorotrifluoromethylation of terminal alkenes, especially styrenes, which had been challenging substrates for previously reported photoredox reactions. This chlorotrifluoromethylation method enables the convenient introduction of a trifluoromethyl group into organic molecules under mild conditions, which is important for medicinal chemistry.
\end{abstract}

\section{INTRODUCTION}

Visible-light photoredox catalysis has become a powerful tool in organic synthesis. ${ }^{1-3}$ Because of their long excited state lifetime, tunable redox potentials, and high stability, coordinatively saturated octahedral $\mathrm{Ru}$ and Ir complexes are the most versatile photocatalysts (PC). Although $\mathrm{Cu}$ complexes have often been employed as alternatives to $\mathrm{Ru}$ and Ir complexes in many photochemical applications, they have only started to be explored as visible-light photoredox catalysts for organic synthesis. ${ }^{4-6}$ Homoleptic $\left[\mathrm{Cu}^{\mathrm{I}}\left(\mathrm{N}^{\wedge} \mathrm{N}\right)_{2}\right]^{+}$ complexes, especially $\left[\mathrm{Cu}(\mathrm{dap})_{2}\right] \mathrm{Cl}(\mathbf{1}$, dap $=2,9-\mathrm{bis}(4-$ anisyl)-1,10-phenanthroline; Figure 1), are the most commonly used $\mathrm{Cu}(\mathrm{I})$ PCs. However, they are limited by short excited state lifetimes (5-10 times lower than $\mathrm{Ru}$ and $\mathrm{Ir}$ counterparts). ${ }^{1,2,7,8}$ Pioneering work of McMillin showed that bulky heteroleptic $\left[\mathrm{Cu}^{\mathrm{I}}\left(\mathrm{N}^{\wedge} \mathrm{N}\right)\left(\mathrm{P}^{\wedge} \mathrm{P}\right)\right]^{+}$complexes (2, Figure 1) could have excited state lifetimes similar to those of $\mathrm{Ru}$ and Ir complexes. ${ }^{9}$ Accordingly, these complexes have been applied to expand the scope of $\mathrm{Cu}$-catalyzed photoredox catalysis. ${ }^{5,10-13}$ So far, the majority of $\mathrm{N}^{\wedge} \mathrm{N}$ ligands in homoleptic and heteroleptic $\mathrm{Cu}$ PCs are 2,9-disubstituted 1,10-phenanthrolines (3, Figure 1), which can be difficult to synthesize and modify. ${ }^{14}$ Increasing the diversity of the $\mathrm{N}^{\wedge} \mathrm{N}$ ligands, on the other hand, is a promising approach to fine-tune the properties and activity of the $\mathrm{Cu}$-based PCs. Toward this goal, we decided to develop substituted 2,2'-bipyridine (bpy) ligands for the assembly of new $\left[\mathrm{Cu}^{\mathrm{I}}\left(\mathrm{N}^{\wedge} \mathrm{N}\right)\left(\mathrm{P}^{\wedge} \mathrm{P}\right)\right]^{+} \mathrm{PCs}$. Although the photophysical studies of some $\mathrm{Cu}$ complexes of bulky bpy ligands are reported, they have not been used in photoredox catalysis. ${ }^{15-17}$

Ligand 4 (Figure 1) was designed for the following reasons: (i) the steric bulk from the methyl group in the 6-position of bpy should hinder excited-state structural relaxation and solvent quenching, leading to a sufficiently long excited state lifetime; (ii) the second pyridine moiety is unsubstituted so the ligand is not too bulky to result in dynamic ligand exchange in solution; ${ }^{18,19}$ (iii) the electron-rich aryl group at the 4-position of bpy renders the ligand harder to reduce, thereby increasing the reduction power of the excited state as the excited state is formally $\left[\mathrm{Cu}^{\mathrm{II}}\left(\mathrm{N}^{\wedge} \mathrm{N}\right)^{-}\left(\mathrm{P}^{\wedge} \mathrm{P}\right)\right]^{+}$; (iv) the 2,4,5-substitution pattern was chosen in order to twist the aryl-ring and prevent extension of the aromaticity which might lower the reduction power of the excited state. Here we report the synthetis, characterization, and catalytic application of two $\left[\mathrm{Cu}^{\mathrm{I}}(4)\right.$ $\left.\left(\mathrm{P}^{\wedge} \mathrm{P}\right)\right]\left[\mathrm{PF}_{6}\right]$ complexes (5 and $\mathbf{6}$, Figure 1$)$, where $\mathrm{P}^{\wedge} \mathrm{P}$ is either bis $\{2$-(diphenylphosphanyl)phenyl $\}$ ether (POP) or 4,5-bis(diphenylphosphino)-9,9-dimethylxanthene (Xantphos). Complex $\left[\mathrm{Cu}^{\mathrm{I}}(4)\right.$ (Xantphos) $]\left[\mathrm{PF}_{6}\right](5)$ is an efficient catalyst for chlorotrifluoromethylation of alkenes, exhibiting the broadest scope for a Cu-based PC. This reaction provides a convenient method to introduce a trifluoromethyl group into organic molecules, which is of high contemporary interest in medicinal chemistry.

Received: August 15, 2018

Published: October 13, 2018 


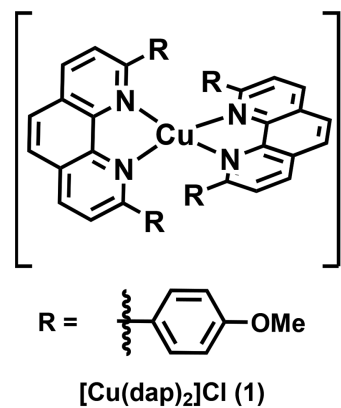

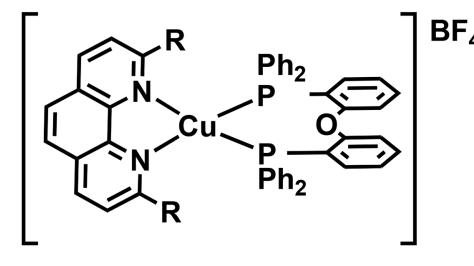

$\mathrm{F}_{4}$<smiles>[R]c1ccc2ccc3ccc([R])nc3c2n1</smiles><smiles>Cc1cc(-c2cc(C)c(C)cc2C)cc(-c2ccccn2)n1</smiles><smiles>CC(C)=[W]</smiles>

4

$6, X=H, H$

Figure 1. $\mathrm{Cu}(\mathrm{I})$ complexes and their ligands in previous and current studies.

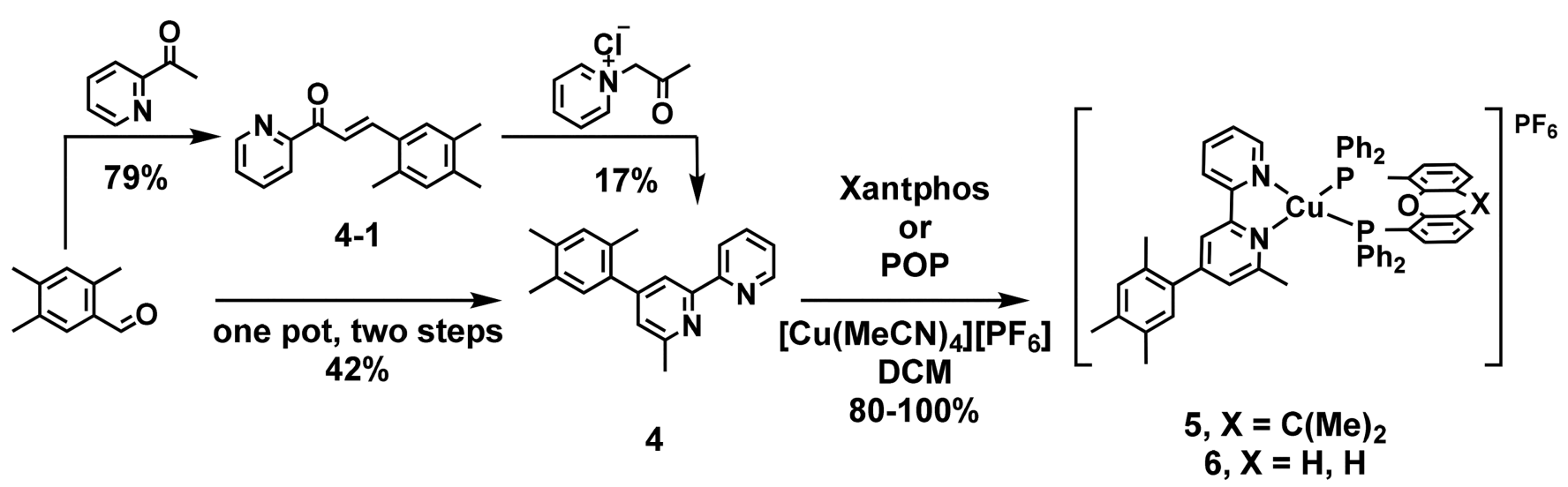

Figure 2. Synthesis of ligand 4 and complexes 5 and $\mathbf{6}$.

\section{RESULTS AND DISCUSSION}

2.1. Synthesis and Characterization of Cu Complexes. A Kröhnke-type synthesis was developed for the bpy ligand 4. Reaction of 2,4,5-trimethylbenzaldehyde with 2-acetylpyridine gave the $\alpha, \beta$-unsaturated carbonyl precursor $4-1$ in $79 \%$ yield. Condensation of 4-1 with $\alpha$-pyridinium methyl ketone salt furnished 4 in $17 \%$ yield. If the two steps were conducted in one pot without isolation of the $\alpha, \beta$-unsaturated carbonyl precursor, the overall yield was improved to $42 \%$ (Figure 2). Mixing of 4 with $\left[\mathrm{Cu}(\mathrm{MeCN})_{4}\right]\left[\mathrm{PF}_{6}\right]$ and Xantphos or POP and recrystallization from $\mathrm{DCM} / \mathrm{Et}_{2} \mathrm{O}$ yielded the $\mathrm{Cu}(\mathrm{I})$ complexes 5 and 6 in $80-100 \%$ yields (Figure 2).

Single X-ray crystallography reveals a distorted tetrahedral geometry for 5 and 6 . The dihedral angle between the $\mathrm{N}-\mathrm{Cu}-$ $\mathrm{N}$ and $\mathrm{P}-\mathrm{Cu}-\mathrm{P}$ planes is $84.74^{\circ}$ for 5 and $85.39^{\circ}$ for 6 , close to the angle of $90^{\circ}$ for a perfect tetrahedron. Notably, the two pyridine rings are significantly twisted with a torsion angle of $18.97^{\circ}$ for 5 and $18.65^{\circ}$ for 6 . The aryl substituent at the 4position is also twisted from the plane of the pyridine ring, with a torsion angle of $50.39^{\circ}$ in 5 and $44.15^{\circ}$ in 6. The methyl group in the 6-position of 4 lies over the $\left(\mathrm{C}_{6} \mathrm{H}_{4}\right)_{2} \mathrm{O}$ unit of POP and the xanthene "bowl" of Xantphos, as observed previously for analogous $\mathrm{Cu}(\mathrm{I})$ compounds. ${ }^{18,20}$ No $\pi$-stacking interaction between $\mathbf{4}$ and Xantphos or POP was observed (Figure 3, Table 1).

Extinction and emission spectra of $\mathbf{5}$ and $\mathbf{6}$ were recorded in acetonitrile $(\mathrm{MeCN})$ and show ligand centered $\left(\pi \rightarrow \pi^{*}\right)$ absorptions in the UV region as well as an MLCT band $\left(\mathrm{d}(\mathrm{Cu}) \rightarrow \pi^{*}\left(\mathrm{~N}^{\wedge} \mathrm{N}\right), \lambda=371\right.$ and $372 \mathrm{~nm}$ for 5 and $\mathbf{6}$, respectively) in the blue region (Figure 4 ). The Xantphoscontaining complex $5\left(\varepsilon=2679 \mathrm{~L} \mathrm{~mol}^{-1} \mathrm{~cm}^{-1}\right)$ has a significantly higher MLCT extinction coefficient than the POP-containing complex $6\left(\varepsilon=1240 \mathrm{~L} \mathrm{~mol}^{-1} \mathrm{~cm}^{-1}\right)$. The lower extinction coefficients of 6 were even visible by the eye, as $\mathbf{6}$ gives a much paler solution compared to $\mathbf{5}$. Emission takes place in the yellow region $(550-600 \mathrm{~nm})$. Both absorption and emission in $\mathbf{5}$ and $\mathbf{6}$ are blue-shifted relative to $\mathbf{1}^{4}$ as well as to $\left[\mathrm{Cu}(\text { bpy })\left(\mathrm{P}^{\wedge} \mathrm{P}\right)\right]^{+}(383$ and $388 \mathrm{~nm}$ for Xantphos and POP, respectively), ${ }^{19}$ suggesting a destabilization of the ligandcentered LUMO. In dichloromethane (DCM), the extinction spectra did not scale with concentration at concentrations $<0.1$ $\mathrm{mM}$, probably due to dynamic ligand dissociation.

Excited state lifetimes were measured via time correlated single photon counting (TCSPC) experiments (Supporting Information, Table S5). The PMMA thin film samples showed a biexponential decay that may arise due to thermally activated 

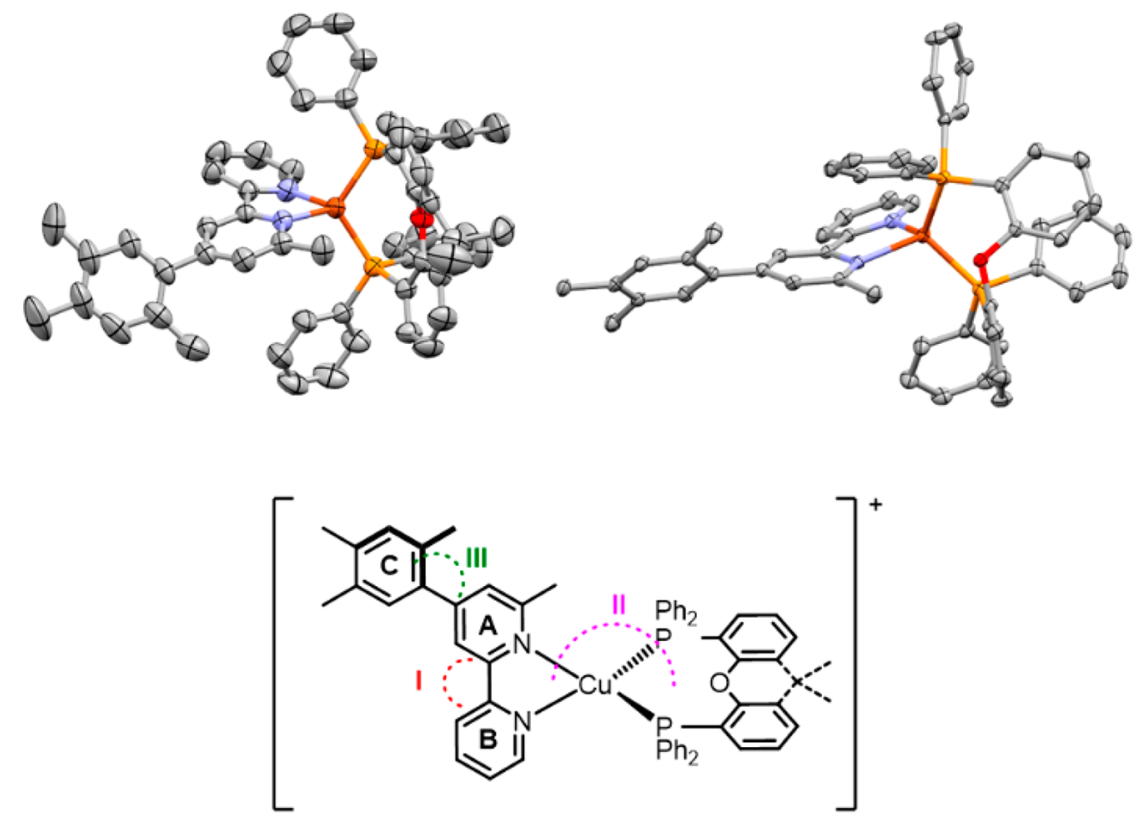

Figure 3. X-ray single-crystal structures of 5 (top left) and 6 (top right). The ellipsoids are plotted at the $50 \%$ probability level. Hydrogens, counterions, and solvent molecules are omitted for clarity. Bottom: $\mathrm{I}=$ torsion angle between rings $\mathrm{A}$ and $\mathrm{B}, \mathrm{II}=$ dihedral angle between the planes containing $\mathrm{N}-\mathrm{Cu}-\mathrm{N}$ and $\mathrm{P}-\mathrm{Cu}-\mathrm{P}, \mathrm{III}=$ torsion angle between rings $\mathrm{A}$ and $\mathrm{C}$.

Table 1. Angles and Distances from X-ray Single Crystal Structures of 5 and 6

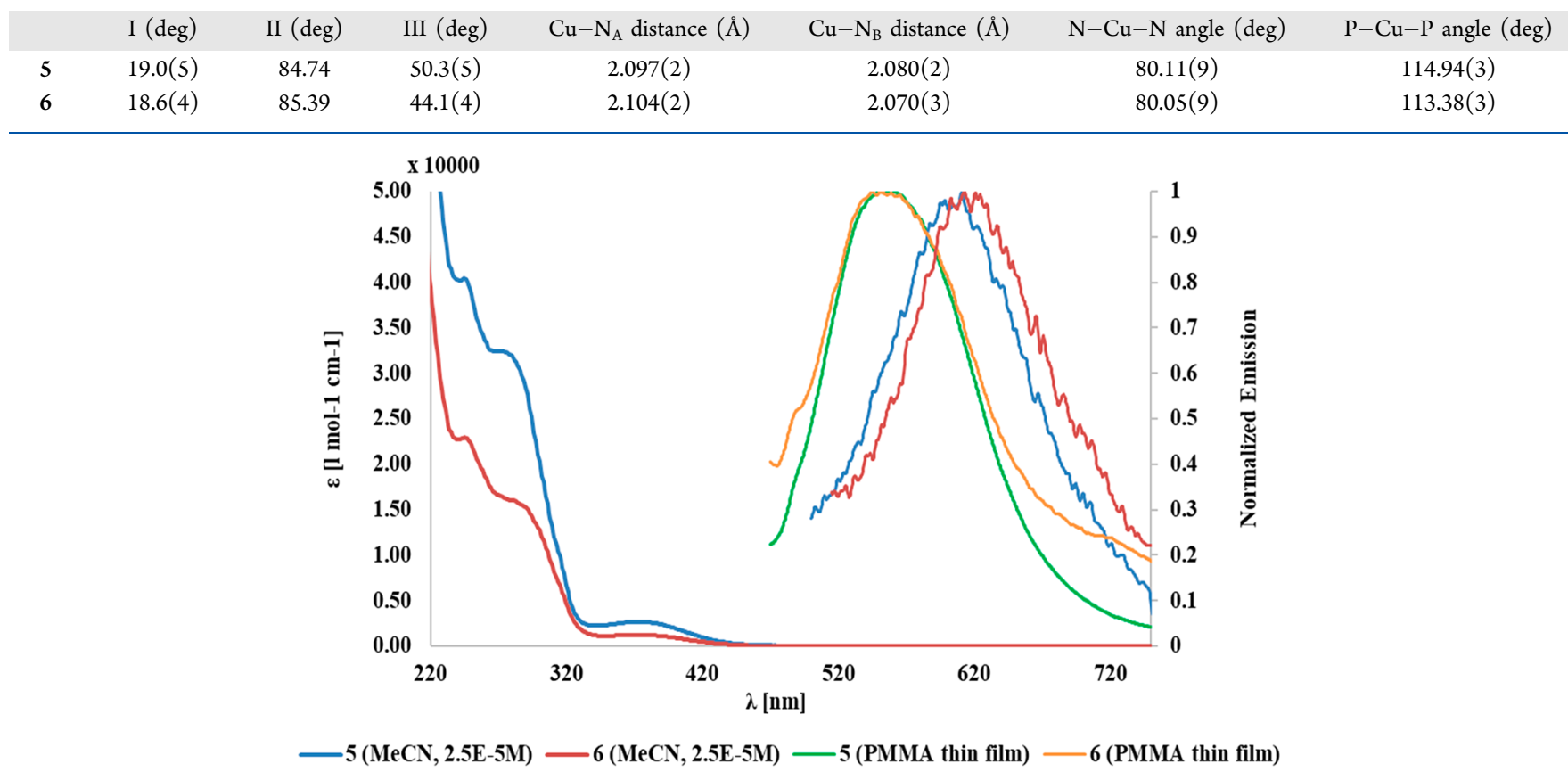

Figure 4. Extinction and emission spectra of 5 and 6 in $\mathrm{MeCN}\left(\lambda_{\mathrm{ex}}=410 \mathrm{~nm}\right)$ and as PMMA thin films $\left(\lambda_{\mathrm{ex}}=400 \mathrm{~nm}\right)$.

delayed fluorescence processes or due to different confomers. In DCM, the data was fitted to monoexponential decays (Supporting Information, Figures S5-S14).

The excited state lifetimes are microseconds for PMMA thin film samples (4.77 and $4.53 \mu$ s for 5 and 6, respectively) and several hundred nanoseconds in DCM. Notably, in solution, 5 has a lifetime $300 \mathrm{~ns}$ longer than 6, $450 \mathrm{~ns}$ longer than 1, 600 ns longer than $\left[\mathrm{Cu}(\text { bpy) }(\text { Xantphos })]^{+}\right.$, and 10 times longer than $[\mathrm{Cu}(\text { bpy })(\mathbf{P O P})]^{+20}$

Complexes 5 and 6 exhibit a quasi-reversible $\mathrm{Cu}(\mathrm{I}) / \mathrm{Cu}(\mathrm{II})$ redox couple in DCM at 1.23 and $1.15 \mathrm{~V}$ vs SCE, respectively
(Supporting Information, Figure S4 and Table S4). These redox potentials are comparable to analogous $\left[\mathrm{Cu}\left(\mathrm{N}^{\wedge} \mathrm{N}\right)\right.$ $\left.\left(\mathrm{P}^{\wedge} \mathrm{P}\right)\right]\left[\mathrm{PF}_{6}\right]$ compounds (Supporting Information, Table $\mathrm{S} 4)^{18,20,21}$ and are about $0.6 \mathrm{~V}$ more positive than the potential for complex $\mathbf{1}(0.6 \mathrm{~V}$ vs SCE). In $\mathrm{MeCN}$, the $\mathrm{Cu}(\mathrm{I})$ / $\mathrm{Cu}$ (II) oxidation is irreversible.

According to the photophysical and electrochemical data, the excited state potentials of 5 and $\mathbf{6}$ were estimated via the Rehm-Weller equation, $E_{\text {ox }}\left([\mathrm{Cu}]^{*}\right)=E_{\text {ox }}(\mathrm{Cu}(\mathrm{I}))-E_{0-0}$ (where $E_{0-0}$ refers to ${ }^{3} \mathrm{MLCT}$ energy, approximated from the emission maximum), as -0.96 and $-1.08 \mathrm{~V}$ vs SCE for 5 and 
6, respectively (Table 2). Thus, the photoexcited states of complexes 5 and 6 exhibit similar reducing power as those of

Table 2. Comparison of Photophysical and Electrochemical Properties between 1, 5, and 6

$\begin{array}{cllccc}\text { complex } & \begin{array}{c}\lambda_{\mathrm{em}} \\ (\mathrm{nm})\end{array} & \begin{array}{c}\mathrm{MLCT} \\ (\mathrm{nm})\end{array} & \begin{array}{c}\tau_{\text {ave }}{ }^{a} \\ (\mathrm{~ns})\end{array} & \begin{array}{c}E^{\mathrm{ox}}{ }^{1 / 2}{ }^{b} \\ (\mathrm{~V} \text { vs SCE})\end{array} & \begin{array}{c}{\left[\mathrm{Cu}^{\mathrm{I}}\right]^{*} /[\mathrm{Cu}]^{\mathrm{II} c}} \\ (\mathrm{~V} \text { vs SCE})\end{array} \\ \mathbf{1}^{d} & 670^{d} & 400-600 & 270 & 0.62 & -1.43 \\ \mathbf{5} & 611^{e_{f} f} & 371^{f} & 720 & 1.23 & -0.96 \\ \mathbf{6} & 613^{e, f} & 372^{f} & 410 & 1.15 & -1.08\end{array}$

${ }^{a}$ Recorded in $\mathrm{N}_{2}$-purged DCM. ${ }^{b}$ Internally referenced vs $\mathrm{Fc}^{0 /+}$ and converted to SCE. ${ }^{2{ }^{c}}$ Estimated via the Rehm-Weller equation. ${ }^{d}$ From ref 6; excitation at $500 \mathrm{~nm}$. ${ }^{e}$ Recorded in MeCN. ${ }^{f}$ Excitation at $410 \mathrm{~nm}$.

$\left[\mathrm{Ru}(\text { phen })_{3}\right]^{2+},\left[\mathrm{Ru}(\mathrm{bpy})_{3}\right]^{2+}$, and $\left[\operatorname{Ir}(\text { ppy })_{2}(\mathrm{dtbpy})\right]^{+}$(Supporting Information, Table S6). They are all less reducing than that of complex $1(-1.43 \mathrm{~V}$ vs SCE) as well as other heteroleptic $\mathrm{Cu}(\mathrm{I})$ complexes, which have excited state potentials of -1.35 to $-2.16 \mathrm{~V}$ vs SCE. ${ }^{5,10-12,22}$

2.2. Catalysis. The activity of 5 and 6 as photoredox catalysts was tested in the chlorotrifluoromethylation reaction of styrenes using $\mathrm{CF}_{3} \mathrm{SO}_{2} \mathrm{Cl}$. While chlorotrifluomethylation of $\alpha, \beta$-unsaturated amides and esters as well as nonactivated alkyl alkenes was achieved using complex $\mathbf{1}^{24,25}$ or $\left[\mathrm{Ru}(\mathrm{phen})_{3}\right]$ $\mathrm{Cl}_{2}{ }^{26}$ as a photoredox catalyst, styrenes have been unsuitable substrates when $\mathrm{CF}_{3} \mathrm{SO}_{2} \mathrm{Cl}$ is used as the trifluoromethylating reagent (except for one special substrate, $p$-nitrostyrene ${ }^{24}$ ). Chlorotrifluomethylation of styrenes via photoredox catalysis was previously only achieved using $\mathrm{Ru}(\mathrm{bpy})_{3}\left(\mathrm{PF}_{6}\right)_{2}$ and Umemoto's reagent. ${ }^{27}$ Compared to Umemoto's reagent, $\mathrm{CF}_{3} \mathrm{SO}_{2} \mathrm{Cl}$ is less expensive and generates only gaseous byproduct $\left(\mathrm{SO}_{2}\right)$ which facilitates separation. Another photo- redox catalyzed pathway to trifluoromethylation of styrenes is fac- $\operatorname{Ir}(\mathrm{ppy})_{3}$ and gaseous $\mathrm{CF}_{3} \mathrm{I}^{28}$ Alternatively, chlorotrifluoromethlyation can be performed using Ru-based catalysts at high temperatures with limited functional group tolerance. ${ }^{29,30}$ Recently, Lin and co-workers also reported an electrocatalytic method for chlorotrifluoromethlyation of olefins which requires equimolar amounts of sacrificial oxidant and shows limited compatibility with electron-rich styrenes. ${ }^{31}$

The reaction of the parent styrene (7) with $\mathrm{CF}_{3} \mathrm{SO}_{2} \mathrm{Cl}$ was used as the test reaction for the optimization of conditions (Table 3). First, complex 5 was used as the PC. The reaction produced two major products: one from chlorotrifluoromethylation (8) and one from chlorotrifluorosulfonation (9). Quantitative conversion was obtained at room temperature (r.t.) after $3 \mathrm{~h}$ using 1 equiv of 7,2 equiv of $\mathrm{CF}_{3} \mathrm{SO}_{2} \mathrm{Cl}, 2$ equiv of $\mathrm{K}_{3} \mathrm{PO}_{4}$ as base, $0.5 \mathrm{~mol} \%$ of $\mathbf{5}$ as $\mathrm{PC}, \mathrm{DCM}$ as solvent ( 3 $\mathrm{mL}$ for $1 \mathrm{mmol}$ scale), LED450 illumination, and under $\mathrm{N}_{2}$. Only 8 and 9 were observed as products by NMR, and the ratio of 8 to 9 was $4: 1$ (entry 1, Table 3). When the LED source is replaced by sunlight, an identical conversion and product selectivity were obtained (entry 2 , Table 3 ).

Control experiments showed that light, catalyst 5 , and $\mathrm{N}_{2}$ atmosphere are all necessary for the reaction (Supporting Information, Figure S1). Without a base, no conversion was observed (entry 3, Table 3). Other bases might be used, with $\mathrm{K}_{2} \mathrm{CO}_{3}$ being the best for both yields and selectivity (entry 4, Table 3 and Supporting Information, entries 1 and 2, Table $\mathrm{S} 1$ ). Lowering the amount of $\mathrm{K}_{2} \mathrm{CO}_{3}$ to 1 equiv led to no conversion (Supporting Information, entry 3, Table S1). Replacing DCM by other solvents such as $\mathrm{MeCN}, \mathrm{THF}$, and DMF significantly lowered the conversion (Supporting Information, entries 4-6, Table S1). Further experiments show that the concentration of reagents and temperature influenced the product selectivity (Supporting Information,

Table 3. Summary of Optimization of Trifluoromethylation of Alkenes

\begin{tabular}{|c|c|c|c|c|c|c|c|c|}
\hline \multicolumn{2}{|c|}{$\begin{array}{rr} & \text { n equiv } \\
7 & (1 \mathrm{mmol} \text { scale })\end{array}$} & \multicolumn{2}{|c|}{$\begin{array}{c}\mathrm{LED}_{450} \\
\mathrm{PC}(0.5 \mathrm{~mol} \%) \\
\text { Base (2 equiv.) } \\
\underset{\mathrm{DCM}(\mathrm{x} \mathrm{mL})}{\longrightarrow} \\
\mathrm{N}_{2} \text { atm } \\
\text { temp, } 3 \mathrm{~h}\end{array}$} & 8 & \multicolumn{2}{|c|}{9} & $-\mathrm{HCl}$ & 10 \\
\hline entry & PC & & base & $n$ & $x$ & temp $\left({ }^{\circ} \mathrm{C}\right)$ & conversion $^{a}(\%)$ & $8 / 9$ \\
\hline 1 & 5 & & $\mathrm{~K}_{3} \mathrm{PO}_{4}$ & 2 & 3 & r.t. & 100 & $4: 1$ \\
\hline $2^{b}$ & 5 & & $\mathrm{~K}_{3} \mathrm{PO}_{4}$ & 2 & 3 & r.t. & 100 & $4: 1$ \\
\hline 3 & 5 & & no & 2 & 3 & r.t. & n.r. ${ }^{c}$ & n.d. ${ }^{c}$ \\
\hline 4 & 5 & & $\mathrm{~K}_{2} \mathrm{CO}_{3}$ & 2 & 3 & r.t. & 100 & $5: 1$ \\
\hline $5^{d}$ & 5 & & $\mathrm{~K}_{2} \mathrm{CO}_{3}$ & 2 & 3 & r.t. & trace & n.d. \\
\hline 6 & 5 & & $\mathrm{~K}_{2} \mathrm{CO}_{3}$ & 2 & 3 & 40 & 100 & $6: 1$ \\
\hline 7 & 5 & & $\mathrm{~K}_{2} \mathrm{CO}_{3}$ & 2 & 5 & r.t. & 100 & $9: 1$ \\
\hline 8 & 5 & & $\mathrm{~K}_{2} \mathrm{CO}_{3}$ & 2 & 5 & 40 & 100 & $9: 1$ \\
\hline 9 & 5 & & $\mathrm{~K}_{2} \mathrm{CO}_{3}$ & 1.2 & 5 & 40 & 100 & $15: 1$ \\
\hline 10 & 6 & & $\mathrm{~K}_{2} \mathrm{CO}_{3}$ & 1.2 & 5 & 40 & 50 & $5: 1$ \\
\hline 11 & 1 & & $\mathrm{~K}_{2} \mathrm{CO}_{3}$ & 1.2 & 5 & 40 & 20 & n.d. \\
\hline 12 & $\mathrm{Ru}(\mathrm{bpy})_{3} \mathrm{C}$ & & $\mathrm{K}_{2} \mathrm{CO}_{3}$ & 1.2 & 5 & 40 & n.r. & n.d. \\
\hline 13 & $\operatorname{Ir}(\text { ppy })_{2}(\mathrm{dt}$ & & $\mathrm{K}_{2} \mathrm{CO}_{3}$ & 1.2 & 5 & 40 & n.r. & n.d. \\
\hline 14 & {$[\mathrm{Cu}(\mathrm{MeCN}$} & & $\mathrm{K}_{2} \mathrm{CO}_{3}$ & 1.2 & 5 & 40 & n.r. & n.d. \\
\hline 15 & Eosin Y & & $\mathrm{K}_{2} \mathrm{CO}_{3}$ & 1.2 & 5 & 40 & n.r. & n.d. \\
\hline 16 & AIBN $(10$ & & $\mathrm{K}_{2} \mathrm{CO}_{3}$ & 1.2 & 5 & 40 & n.r. & n.d. \\
\hline
\end{tabular}

${ }^{a}$ Determined by ${ }^{1} \mathrm{H}$ NMR. ${ }^{b}$ Illumination by sunlight. ${ }^{c}$ n.r. $=$ no reaction; n.d. $=$ not determined. ${ }^{d} 1$ equiv of base. 

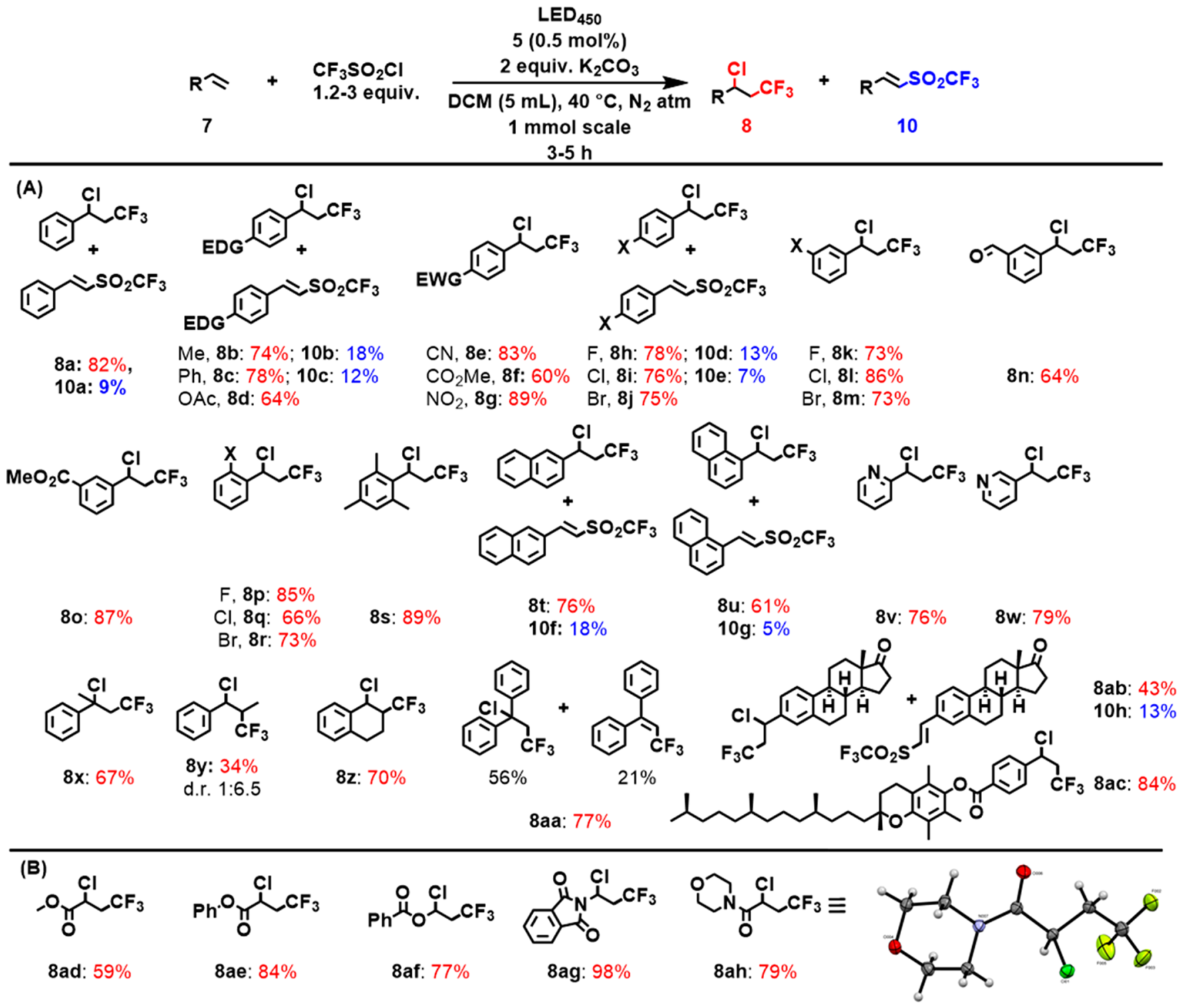

(C)

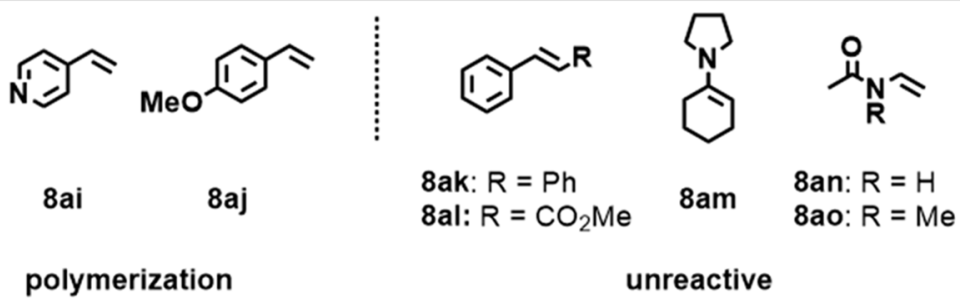

Figure 5. Scope of chlorotrifluoromethylation with styrenes (A), terminal alkenes with adjacent electron withdrawing groups (B), and limitation of chlorotrifluoromethylation with unsuccessful substrates (C).

Table S2). A higher $\mathbf{8 / 9}$ ratio was obtained when the temperature was increased from r.t. to $40{ }^{\circ} \mathrm{C}$ (compare entries 1 and 6, Table 3 ) or when the solution volume was increased from 3 to $5 \mathrm{~mL}$ (compare entries 1 and 7, Table 3). The amount of $\mathrm{CF}_{3} \mathrm{SO}_{2} \mathrm{Cl}$ could be decreased to 1.2 equiv (entry 8 , Table 3). The best selectivity of $15: 1$ was achieved using 2 equiv of $\mathrm{K}_{2} \mathrm{CO}_{3}$ as base in $5 \mathrm{~mL}$ of $\mathrm{DCM}$ at $40{ }^{\circ} \mathrm{C}$ (entry 9 , Table 3). Replacement of $\mathbf{5}$ with $\mathbf{6}$ as PC reduced the conversion to only $50 \%$ and the selectivity to $5: 1$ (entry 10 , Table 3). Other $\mathrm{Ru}, \mathrm{Ir}, \mathrm{Cu}$, and organic PCs were tested, but all gave lower to no conversions (Supporting Information, Table S3). For example, using 1, the conversion was only $20 \%$ (entry 11, Table 3); using $\operatorname{Ir}(\mathrm{ppy})_{3}$, the conversion was only $26 \%$ (Supporting Information, entry 4, Table S3). Ru(bpy) ${ }_{3} \mathrm{Cl}_{2}, \operatorname{Ir}(\mathrm{ppy})_{2}(\mathrm{dtbbpy}) \mathrm{PF}_{6},\left[\mathrm{Cu}(\mathrm{MeCN})_{4}\right] \mathrm{PF}_{6}$, and Eosin $\mathrm{Y}$ were all ineffective (entries 12-15, Table 3). A radical initiator, AIBN, also failed to initiate the reaction (entry 16, Table 3). During the attempt to isolate 8 and 9 from the reaction conducted under the optimized conditions (entry 9 , Table 3), it was found that 9 is sensitive to water and rapidly eliminates $\mathrm{HCl}$ during isolation to yield 10. The overall isolated yield was $91 \%$, and the $\mathbf{8 / 1 0}$ ratio was larger than $6: 1$.

The optimized conditions were successfully applied for chlorotrifluoromethylation of a wide range of terminal styrenes 


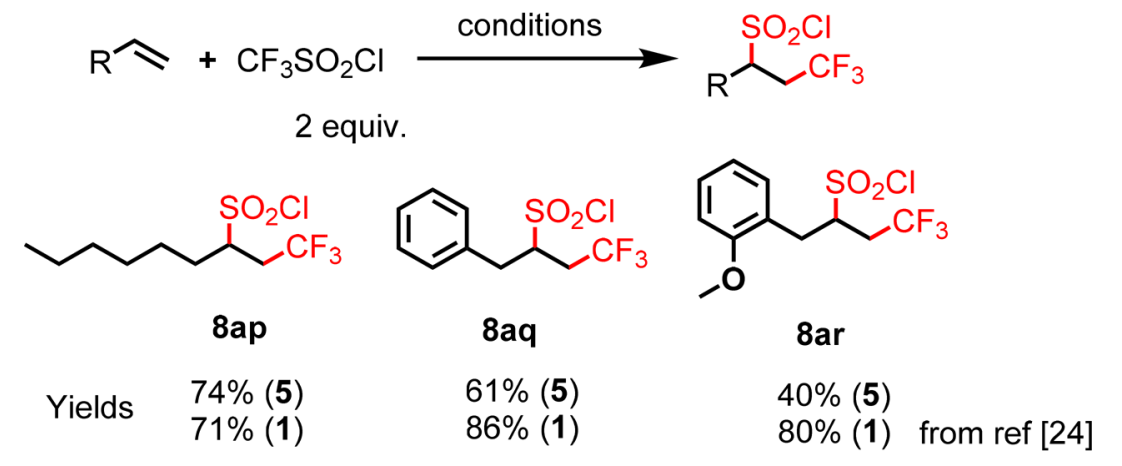

Figure 6. Reactions with aliphatic terminal alkenes. See the Supporting Information and ref 24 for reaction conditions.

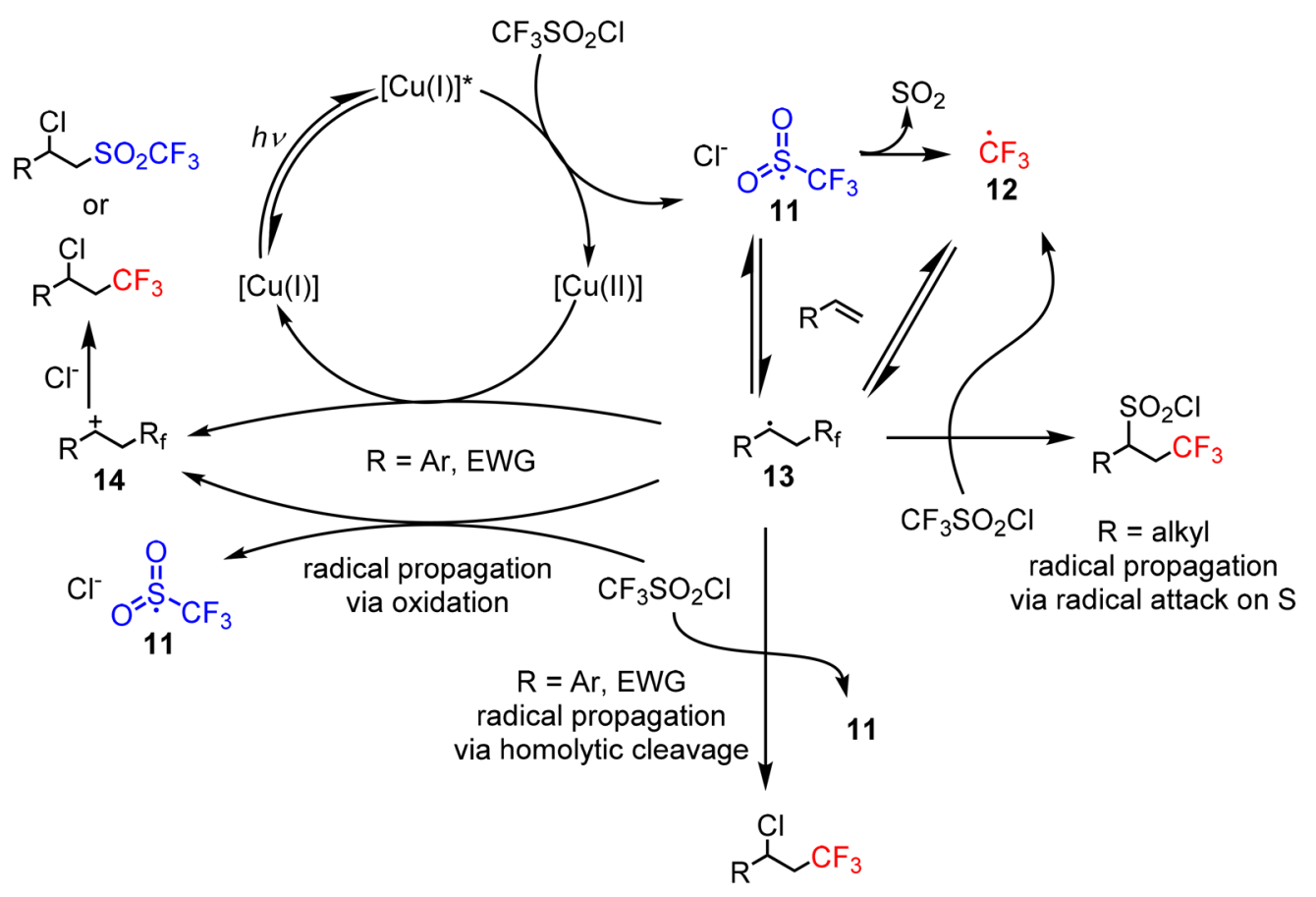

Figure 7. Proposed mechanism for trifluoromethylation and trifluorosulfonation of alkenes.

(Figure 5A). Though in some cases a minor amount of formal trifluorosulfonation product (vide supra) was formed, the majority of substrates underwent exclusive chlorotrifluomethylation. Electron-neutral, -withdrawing, or -donating groups at the para-, meta-, and ortho-positions are all tolerated $(\mathbf{8 a}-\mathbf{8 r}$, 10a-10e). Chlorotrifluoromethylation also worked for 2,4,6trimethylstyrene, suggesting that the reaction was insensitive to steric hindrance at the aryl group (8s). Alkenes substituted by other aromatic groups such as naphthyl $(\mathbf{8 t}-\mathbf{8 u}, \mathbf{1 0 f}-\mathbf{1 0 g})$ and pyridinyl $(\mathbf{8 v}-\mathbf{8 w})$ could be used as well. The $\alpha$-position of styrene could be further substituted by a methyl group $(\mathbf{8 x})$, while analogous substitution at the $\beta$-position led to a diminished yield $(34 \% ; 8 y)$. On the other hand, 1,2dihydronaphthalene was chlorotrifluoromethylated in $70 \%$ yield $(\mathbf{8 z})$. These results indicated that the reaction was sensitive to the sterics at the $\beta$-position of the styrene. The chlorotrifluoromethylation product of 1,1-diphenylethylene was prone to $\mathrm{HCl}$ elimination (8aa). Thus, $21 \%$ of chlorotrifluoromethylation and $56 \%$ of formal oxidative trifluoromethylation products were obtained from this reaction. The reactions tolerated various functional groups such as ester (8d, 8f, 8o), nitrile (8e), nitro $(\mathbf{8 g}), \mathrm{F}$ (8h, 10d, $8 \mathbf{k}, 8 \mathbf{p}), \mathrm{Cl}(\mathbf{8 i}, 10 \mathbf{e}, 8 \mathbf{1}, 8 \mathbf{q}), \mathrm{Br}(\mathbf{8 j}, \mathbf{8 m}, 8 \mathbf{r})$, and pyridine $(8 \mathbf{v}$, $\mathbf{8 w})$. The tolerance of this method was further demonstrated in the successful chlorotrifluoromethylation of substrate derived from estrone (8ab and $\mathbf{1 0 h}$ ) and $\alpha$-tocopherol (8ac). Besides styrene derivatives, terminal alkenes with adjacent electron withdrawing groups, such as ester (8ad-8af), phthalimide (8ag), and amide (8ah), were also viable substrates (Figure $5 b)$. The structure of $8 \mathrm{ah}$ was determined by single-crystal Xray crystallography. The limitations of the method were also explored (Figure 5c). Significant polymerization was observed for 4-vinylpyridine (8ai) and 1-methoxy-4-vinylbenzene (8aj) under the reaction conditions. Internal alkenes such as stilbene (8ak) and methylcinnamate (8al) were unreactive. Likewise, alkenes with a $\mathrm{N}$ group at the 2-position $(\mathbf{8 a m}-\mathbf{8 a o})$ did not react.

Alkyl substituted terminal alkenes were then tested as substrates. However, the reactions led to chlorosulfonation at the 2-position and trifluomethylation at the 1-position (Figure 6). Complex 1 was previously shown to be an efficient catalyst for such reactions. ${ }^{24}$ Indeed, for some substrates, e.g., 8aq and 8ar, the yields were higher using $\mathbf{1}$ instead of $\mathbf{5}$ as the PC. Thus, the reactions catalyzed by $\mathbf{5}$ were not further explored.

On the basis of previous studies of analogous trifluomethylation reactions of alkenes ${ }^{24,25,32}$ and the reaction outcomes 
observed in this study, a mechanistic hypothesis is proposed (Figure 7).

The photoexcited state of the $\mathrm{Cu}$ catalyst $\left(5^{*}\right)$ undergoes oxidative quenching by $\mathrm{CF}_{3} \mathrm{SO}_{2} \mathrm{Cl}\left(E_{\mathrm{red}}=-0.18 \mathrm{~V}\right.$ vs $\left.\mathrm{SCE}^{33}\right)$ to give the $\mathrm{CF}_{3} \mathrm{SO}_{2}{ }^{\bullet}$ radical (11) and initiate the reaction. While some 11 is immediately trapped by the olefin, the majority of it extrudes $\mathrm{SO}_{2}$ to give $\mathrm{CF}_{3}{ }^{\bullet}$ radical (12), which then adds to the olefin as well. The addition product is an alkyl radical (13) that can engage in various reaction pathways to generate the observed products. When the alkene is substituted by an aryl or electron withdrawing group, 13 might be oxidized either by the oxidized $\mathrm{Cu}$ (II) $\mathrm{PC}$ or by $\mathrm{CF}_{3} \mathrm{SO}_{2} \mathrm{Cl}$ to give an alkyl cation (14). In the former case, the PC is regenerated; in the latter case, 11 is generated so the radical propagates. 14 then recombines with a $\mathrm{Cl}^{-}$anion to give the product. Alternatively, 13 might abstract a $\mathrm{Cl}^{\bullet}$ radical from $\mathrm{CF}_{3} \mathrm{SO}_{2} \mathrm{Cl}$ to give directly the product and a new $\mathrm{CF}_{3} \mathrm{SO}_{2}{ }^{\circ}$, propagating the radical chain reaction. These pathways might coexist. If the alkene is substituted by a nonactivated alkyl group, then the alkyl radical 13 prefers to attack the $\mathrm{S}$ instead of $\mathrm{Cl}$ of $\mathrm{CF}_{3} \mathrm{SO}_{2} \mathrm{Cl}$ to give the chlorosulfonation product. We found no evidence or reason to include the previously proposed innersphere mechanism for $\mathrm{Cu}(\mathrm{I})$ photoredox catalyzed trifluoromethylchlorosulfonylation. ${ }^{24}$ A dedicated study is required to elucidate the details of the mechanism.

The higher catalytic efficiency of $\mathbf{5}$ compared to other $\mathrm{Cu}$ PCs for chlorotrifluoromethylation of styrenes warrants some comments. 5 has higher extinction coefficients than 6 , which might be beneficial for absorption of photons leading to an MLCT and thus photocatalysis. Furthermore, the longer excited state lifetime of 5 compared to $\mathbf{6}$ may also contribute to its higher catalytic efficiency. The $\mathrm{Cu}(\mathrm{I}) / \mathrm{Cu}(\mathrm{II})$ redox couple of $\mathbf{5}$ is much more positive than that of $\mathbf{1}$. Thus, the regeneration of $\mathbf{5}$ through the reaction of the alkyl radical $\mathbf{1 3}$ with the $\mathrm{Cu}$ (II) form of the catalyst is more facile than the regeneration of $\mathbf{1}$ in an analogous reaction.

\section{CONCLUSION}

Two heteroleptic $\left[\mathrm{Cu}^{\mathrm{I}}\left(\mathrm{N}^{\wedge} \mathrm{N}\right)\left(\mathrm{P}^{\wedge} \mathrm{P}\right)\right]\left[\mathrm{PF}_{6}\right]$ complexes containing a new 4,6-disubstituted 2,2'-bipyridine ligand have been synthesized and characterized. The complexes exhibit longer excited state lifetimes and more positive $\mathrm{Cu}(\mathrm{I}) / \mathrm{Cu}(\mathrm{II})$ redox couples than the classic $\mathrm{Cu}$-based photoredox catalyst $\left[\mathrm{Cu}(\text { dap })_{2}\right] \mathrm{Cl}$. Using complex $\left[\mathrm{Cu}^{\mathrm{I}}(4)\right.$ (Xantphos) $]\left[\mathrm{PF}_{6}\right]$ (5), the first general photoredox catalyzed chlorotrifluoromethylation of styrenes has been achieved, with broad substrate scope and high functional group tolerance. The work demonstrates the potential of substituted 2,2'-bipyridine ligands for $\mathrm{Cu}$ based photoredox catalysis.

\section{ASSOCIATED CONTENT}

\section{S Supporting Information}

The Supporting Information is available free of charge on the ACS Publications website at DOI: 10.1021/acs.organomet.8b00585.

Experimental details and characterization data (PDF)

\section{Accession Codes}

CCDC 1850074-1850076 contain the supplementary crystallographic data for this paper. These data can be obtained free of charge via www.ccdc.cam.ac.uk/data_request/cif, or by emailingdata_request@ccdc.cam.ac.uk, or by contacting The
Cambridge Crystallographic Data Centre, 12 Union Road, Cambridge CB2 1EZ, UK; fax: +44 1223336033.

\section{AUTHOR INFORMATION}

\section{Corresponding Author}

*E-mail: xile.hu@epfl.ch.

ORCID $\odot$

Xile Hu: 0000-0001-8335-1196

\section{Author Contributions}

The manuscript was written through contributions of all authors. All authors have given approval to the final version of the manuscript.

\section{Notes}

The authors declare no competing financial interest.

\section{ACKNOWLEDGMENTS}

We thank Laurent Liardet (EPFL) for help with electrochemical measurements and Dr. Anne-Sophie Chauvin (EPFL) for conducting the TCSPC measurements. Dr. Rosario Scopelliti (EPFL) and Dr. Farzaneh Fadaei Tirani (EPFL) are acknowledged for the X-ray crystallography. This work is funded by the Swiss National Science Foundation (no. 200020 162362).

\section{REFERENCES}

(1) Narayanam, J. M. R.; Stephenson, C. R. J. Visible light photoredox catalysis: applications in organic synthesis. Chem. Soc. Rev. 2011, 40 (1), 102-113.

(2) Prier, C. K.; Rankic, D. A.; MacMillan, D. W. C. Visible Light Photoredox Catalysis with Transition Metal Complexes: Applications in Organic Synthesis. Chem. Rev. 2013, 113 (7), 5322-5363.

(3) Romero, N. A.; Nicewicz, D. A. Organic Photoredox Catalysis. Chem. Rev. 2016, 116 (17), 10075-10166.

(4) Paria, S.; Reiser, O. Copper in Photocatalysis. ChemCatChem 2014, 6 (9), 2477-2483.

(5) Reiser, O. Shining Light on Copper: Unique Opportunities for Visible-Light-Catalyzed Atom Transfer Radical Addition Reactions and Related Processes. Acc. Chem. Res. 2016, 49 (9), 1990-1996.

(6) Larsen, C. B.; Wenger, O. S. Photoredox Catalysis with Metal Complexes Made from Earth-Abundant Elements. Chem. - Eur. J. 2018, 24 (9), 2039-2058.

(7) Kern, J.-M.; Sauvage, J.-P. Photoassisted C-C coupling via electron transfer to benzylic halides by a bis(di-imine) copper(I) complex. J. Chem. Soc., Chem. Commun. 1987, No. 8, 546-548.

(8) Pirtsch, M.; Paria, S.; Matsuno, T.; Isobe, H.; Reiser, O. $[\mathrm{Cu}(\mathrm{dap}) 2 \mathrm{Cl}]$ As an Efficient Visible-Light-Driven Photoredox Catalyst in Carbon-Carbon Bond-Forming Reactions. Chem. - Eur. J. 2012, 18 (24), 7336-7340.

(9) Cuttell, D. G.; Kuang, S.-M.; Fanwick, P. E.; McMillin, D. R.; Walton, R. A. Simple $\mathrm{Cu}(\mathrm{I})$ Complexes with Unprecedented ExcitedState Lifetimes. J. Am. Chem. Soc. 2002, 124 (1), 6-7.

(10) Hernandez-Perez, A. C.; Collins, S. K. Heteroleptic Cu-Based Sensitizers in Photoredox Catalysis. Acc. Chem. Res. 2016, 49 (8), $1557-1565$.

(11) Michelet, B.; Deldaele, C.; Kajouj, S.; Moucheron, C.; Evano, G. A General Copper Catalyst for Photoredox Transformations of Organic Halides. Org. Lett. 2017, 19 (13), 3576-3579.

(12) Minozzi, C.; Caron, A.; Grenier-Petel, J. C.; Santandrea, J.; Collins, S. K. Heteroleptic Copper(I)-Based Complexes for Photocatalysis: Combinatorial Assembly, Discovery, and Optimization. Angew. Chem., Int. Ed. 2018, 57 (19), 5477-5481.

(13) Cetin, M. M.; Hodson, R. T.; Hart, C. R.; Cordes, D. B.; Findlater, M.; Casadonte, D. J., Jr; Cozzolino, A. F.; Mayer, M. F. Characterization and photocatalytic behavior of 2,9-di(aryl)-1,10- 
phenanthroline copper(i) complexes. Dalton Transactions 2017, 46 (20), 6553-6569.

(14) Armaroli, N.; Accorsi, G.; Cardinali, F.; Listorti, A. Photochemistry and Photophysics of Coordination Compounds: Copper. In Photochemistry and Photophysics of Coordination Compounds I; Balzani, V., Campagna, S., Eds.; Springer: Berlin, Heidelberg, 2007; pp 69115 .

(15) Brunner, F.; Martinez-Sarti, L.; Keller, S.; Pertegas, A.; Prescimone, A.; Constable, E. C.; Bolink, H. J.; Housecroft, C. E. Peripheral halo-functionalization in $\left[\mathrm{Cu}\left(\mathrm{N}^{\wedge} \mathrm{N}\right)\left(\mathrm{P}^{\wedge} \mathrm{P}\right)\right]+$ emitters: influence on the performances of light-emitting electrochemical cells. Dalton Transactions 2016, 45 (38), 15180-15192.

(16) Brunner, F.; Graber, S.; Baumgartner, Y.; Haussinger, D.; Prescimone, A.; Constable, E. C.; Housecroft, C. E. The effects of introducing sterically demanding aryl substituents in $\left[\mathrm{Cu}\left(\mathrm{N}^{\wedge} \mathrm{N}\right)\right.$ $\left.\left(\mathrm{P}^{\wedge} \mathrm{P}\right)\right]+$ complexes. Dalton Transactions 2017, 46 (19), 6379-6391. (17) Alkan-Zambada, M.; Keller, S.; Martínez-Sarti, L.; Prescimone, A.; Junquera-Hernández, J. M.; Constable, E. C.; Bolink, H. J.; Sessolo, M.; Ortí, E.; Housecroft, C. E. $\left[\mathrm{Cu}\left(\mathrm{P}^{\wedge} \mathrm{P}\right)\left(\mathrm{N}^{\wedge} \mathrm{N}\right)\right][\mathrm{PF} 6]$ compounds with bis(phosphane) and 6-alkoxy, 6-alkylthio, 6phenyloxy and 6-phenylthio-substituted 2,2'-bipyridine ligands for light-emitting electrochemical cells. J. Mater. Chem. C 2018, 6 (31), $8460-8471$.

(18) Keller, S.; Pertegas, A.; Longo, G.; Martinez, L.; Cerda, J.; Junquera-Hernandez, J. M.; Prescimone, A.; Constable, E. C.; Housecroft, C. E.; Orti, E.; Bolink, H. J. Shine bright or live long: substituent effects in $\left[\mathrm{Cu}\left(\mathrm{N}^{\wedge} \mathrm{N}\right)\left(\mathrm{P}^{\wedge} \mathrm{P}\right)\right]+$-based light-emitting electrochemical cells where $\mathrm{N}^{\wedge} \mathrm{N}$ is a 6-substituted 2,2[prime or minute]bipyridine. J. Mater. Chem. C 2016, 4 (17), 3857-3871.

(19) Kaeser, A.; Mohankumar, M.; Mohanraj, J.; Monti, F.; Holler, M.; Cid, J.-J.; Moudam, O.; Nierengarten, I.; Karmazin-Brelot, L.; Duhayon, C.; Delavaux-Nicot, B.; Armaroli, N.; Nierengarten, J.-F. Heteroleptic Copper(I) Complexes Prepared from Phenanthroline and Bis-Phosphine Ligands. Inorg. Chem. 2013, 52 (20), 1214012151.

(20) Keller, S.; Brunner, F.; Junquera-Hernández, J. M.; Pertegás, A.; La-Placa, M.-G.; Prescimone, A.; Constable, E. C.; Bolink, H. J.; Ortí, E.; Housecroft, C. E. CF3 Substitution of $\left[\mathrm{Cu}\left(\mathrm{P}^{\wedge} \mathrm{P}\right)(\mathrm{bpy})\right][\mathrm{PF} 6]$ Complexes: Effects on Photophysical Properties and Light-Emitting Electrochemical Cell Performance. ChemPlusChem 2018, 83 (4), 217-229.

(21) Keller, S.; Constable, E. C.; Housecroft, C. E.; Neuburger, M.; Prescimone, A.; Longo, G.; Pertegás, A.; Sessolo, M.; Bolink, H. J. $\left[\mathrm{Cu}(\right.$ bpy $\left.)\left(\mathrm{P}^{\wedge} \mathrm{P}\right)\right]+$ containing light-emitting electrochemical cells: improving performance through simple substitution. Dalton Transactions 2014, 43 (44), 16593-16596.

(22) Knorn, M.; Rawner, T.; Czerwieniec, R.; Reiser, O. [Copper(phenanthroline)(bisisonitrile)]+-Complexes for the Visible-LightMediated Atom Transfer Radical Addition and Allylation Reactions. ACS Catal. 2015, 5 (9), 5186-5193.

(23) Pavlishchuk, V. V.; Addison, A. W. Conversion constants for redox potentials measured versus different reference electrodes in acetonitrile solutions at 25 degrees C. Inorg. Chim. Acta 2000, 298 (1), 97-102.

(24) Bagal, D. B.; Kachkovskyi, G.; Knorn, M.; Rawner, T.; Bhanage, B. M.; Reiser, O. Trifluoromethylchlorosulfonylation of Alkenes: Evidence for an Inner-Sphere Mechanism by a Copper Phenanthroline Photoredox Catalyst. Angew. Chem., Int. Ed. 2015, 54 (24), 6999-7002.

(25) Tang, X. J.; Dolbier, W. R. Efficient Cu-catalyzed Atom Transfer Radical Addition Reactions of Fluoroalkylsulfonyl Chlorides with Electron-deficient Alkenes Induced by Visible Light. Angew. Chem., Int. Ed. 2015, 54 (14), 4246-4249.

(26) Oh, S. H.; Malpani, Y. R.; Ha, N.; Jung, Y.-S.; Han, S. B. Vicinal Difunctionalization of Alkenes: Chlorotrifluoromethylation with CF3SO2Cl by Photoredox Catalysis. Org. Lett. 2014, 16 (5), $1310-1313$.
(27) Carboni, A.; Dagousset, G.; Magnier, E.; Masson, G. ThreeComponent Photoredox-Mediated Chloro-, Bromo-, or Iodotrifluoromethylation of Alkenes. Synthesis 2015, 47 (16), 2439-2445.

(28) Straathof, N. J. W.; Cramer, S. E.; Hessel, V.; Noël, T. Practical Photocatalytic Trifluoromethylation and Hydrotrifluoromethylation of Styrenes in Batch and Flow. Angew. Chem., Int. Ed. 2016, 55 (50), $15549-15553$.

(29) Kamigata, N.; Fukushima, T.; Terakawa, Y.; Yoshida, M.; Sawada, H. Novel perfluoroalkylation of alkenes with perfluoroalkanesulphonyl chlorides catalysed by a ruthenium(II) complex. J. Chem. Soc., Perkin Trans. 1 1991, No. 3, 627-633.

(30) Kamigata, N.; Fukushima, T.; Yoshida, M. Reaction of trifluoromethanesulphonyl chloride with alkenes catalysed by a ruthenium(II) complex. J. Chem. Soc., Chem. Commun. 1989, No. 20, 1559-1560.

(31) Ye, K.-Y.; Pombar, G.; Fu, N.; Sauer, G. S.; Keresztes, I.; Lin, S. Anodically Coupled Electrolysis for the Heterodifunctionalization of Alkenes. J. Am. Chem. Soc. 2018, 140 (7), 2438-2441.

(32) Rawner, T.; Knorn, M.; Lutsker, E.; Hossain, A.; Reiser, O. Synthesis of Trifluoromethylated Sultones from Alkenols Using a Copper Photoredox Catalyst. J. Org. Chem. 2016, 81 (16), 71397147.

(33) Nagib, D. A.; MacMillan, D. W. C. Trifluoromethylation of arenes and heteroarenes by means of photoredox catalysis. Nature 2011, 480, 224. 